\title{
Research on the Costs of Running Compulsory Education Standards: Comparison of Compulsory Education Internationally
}

\author{
Yongli Jin \\ President of Schools of Industrial and Commercial Management \\ Shenyang University, Shenyang 110041, China \\ Tel: 86-137-0405-0825 E-mail: jylsydx@163.com \\ Hong Zhang \\ President of Schools of Industrial and Commercial Management \\ Shenyang University, Shenyang 110041, China \\ Tel: 86-138-8931-8655 E-mail: zhanghong_syu@126.com
}

\begin{abstract}
Compulsory education is the fundamental education for citizens and is the source of state power, which radically determines thought level, political awareness, cultural sense and production ability of the entire nation. Therefore, to popularize compulsory education is the root of a country. This paper explains the meanings of compulsory education, compares domestic compulsory education with those abroad, reviews and illustrates the past and present conditions of China's compulsory education, and puts forward development direction of China's compulsory education.
\end{abstract}

Keywords: Compulsory education, International comparison, Present condition, Perspective

Compulsory education is the product of the development of modern industrial production and modern social life. The practices of other countries in popularizing compulsory education teach us that compulsory education is the education of the entire human beings and the education of social citizens. The aim of education is to facilitate each social citizen with basic, systematical and comprehensive scientific and cultural knowledge. Compulsory education does not aim at cultivating talents but at cultivating human being, Compulsory education is to help each human being to have good personalities and healthy bodies, to master the knowledge, skills and methods to continue study, to take on excellent psychological makings and scientific life attitudes, and to become qualified citizens who abide by laws and could distinguish right from wrong.

\section{The concept of compulsory education}

Compulsory education is also called imposed education, free education or popularizing compulsory education. Compulsory education is, according to the state laws and regulations, widespread, compulsory and free school education during limited years, within limited extent, on children at the right age. It is fundamental education that the society and families should guarantee, is indispensable to modern production and modern life, and is the mark of modern civilization. Compulsory education is an important component of citizen education and has remarkable characteristics, namely, compulsory and popularized.

\section{Comparison of domestic compulsory education with those abroad}

Compulsory education was adopted due to the establishment of new countries, is considered important as the driving power of a country's development, and has been developed with the rising and declining of nationalism. In this way, compulsory education is combined with countries' aims, which helps to develop compulsory education. Particularly, after the second world war, with the penetrating of democracy cosmopolitan, human right starts to gain importance in the field of education. It has been widely admitted that to be educated is the right of human beings, which totally differs from the previous right-obligation relationship, that is, receiving education is the obligation of citizens and offering education is the right of the country. Of course, compulsory education concept changes with it. Receiving compulsory education is the lowest right of citizens and further guaranteeing compulsory education becomes the obligation of the country. The developments of compulsory educations in different countries vary with each other due to the difference in social and cultural background.

\subsection{Compulsory education in five high-income countries, namely, the US, Soviet Russia, the UK, France and Japan}

After the second world war, the US adopted 12-year compulsory education. The resources of education funds of the US are diversified. In addition to government funds and tuition, social donation and the incomes from schools' service to 
the society also account for a large portion. Soviet Russia conducted 10-year compulsory education, where poor students enjoyed totally or partly free text books. The UK established 11-year compulsory education. In 1967, the UK announced that the "age-11 examination" was cancelled, children of various classes could directly enter comprehensive schools from elementary schools and enjoy free tuition. In 1959, France issued Education Report Order, stating that France would execute 10-year compulsory education, tuition was exempted, poor students were exempted from book expenses, all students enjoyed transportation and lunch subsidy. After the second world war, the compulsory education of Japan regulated that all citizens aged from six to fifteen must receive 9-year compulsory education (6-year elementary school and 3-year junior high school), tuition and book expenses were free and part of the lunch fees were free too. In the education investment distribution structure, all the five countries follow the rule of "guaranteeing the common, develop the important and guaranteeing the investment on popularizing compulsory education". Because of different economic development levels of the five countries and different significance attached to compulsory education, the investment amount and apportionment on compulsory education of the five countries differ from each other.

\subsection{Compulsory education in countries of mid-high incomes-Brazil and Mexico}

Brazil executes 8-year compulsory education. Its education administrative system is divided into three levels: federal level, state level and municipal level. Brazil established fundamental education maintaining and development and teaching promotion funds so as to encourage education co-workers to participate in the activities and to resolve problems in education finance. Mexico carries out 10-year compulsory education, including one year of pre-school education where students do not need to pay tuition and text book fees. Its funds mainly come from the Ministry of Education. Each year the government will give two hundred million Piaster (equivalent to RMB one hundred and fifty million) to community education. The two countries are mid-high income countries in Latin America with the biggest population. Therefore, they are of representation. After 1960s, because the two countries have been attaching significance to compulsory education investment, the development status of popularizing compulsory education is rather good.

\subsection{Compulsory education in countries of mid-low incomes- Egypt and Nigeria}

Egypt carries out 9-year compulsory education. Students are exempted from tuition and text book fees. Nigeria executes 6-year compulsory education. In countries of mid-low incomes, the proportion of funds invested in compulsory education shows downtrend. Between 1965 and 1985, the proportion of funds invested by the government on compulsory decreased 3 percent at average. In particular, the proportion of funds invested in preliminary education decreases greatly, $7 \%$ at average. Such trend will affect the sound development of compulsory education.

\subsection{Compulsory education in countries of low incomes-India and Pakistan}

The free compulsory education in India is 8 years. Its education administrative system is composed of federal, state, county or autonomy city (town), district or village levels. India adopts the administrative system where central government and state have different and separate powers. Pakistan also executes 8-year compulsory education. Countries of low incomes are under huge tasks in compulsory education. They are short of funds to be invested in compulsory education and their benefits from compulsory education are low, which is mainly showed in that the ratio of compulsory education students discontinuing their studies is high and the ratio between teachers and students is low. Such phenomenon is common in countries of low incomes and shall arouse attention.

\subsection{China's compulsory education - transition from mid-low income country to middle income country}

China's compulsory education is, according to the regulations of P.R.C. Compulsory Education Law, citizen education that children and teenagers of the right age must receive and state, society, schools and families must provide. Compulsory education could be divided into preliminary compulsory education and preliminary middle compulsory education. As regulated by P.R.C. Compulsory Education Law, the compulsory education of China is 9 years. At present, the length of schooling of compulsory education mainly includes "six-three system" (six years of elementary school and three years of junior high school) and "five-four system" (five years of elementary school and four years of junior high school). Also, there are some places where 8-year compulsory education is executed, that is five years of elementary school and three years of junior high school. However, these areas are transiting to 9-year compulsory education. Children and teenagers of the right ages, after finishing the 9-year or 8-year compulsory education study, will achieve a degree of junior high school graduation. The state exempts students receiving compulsory education from the tuition.

In 169 countries where data are available, the mean year of compulsory education is 7 to 8 years. African countries have 6-year compulsory education and north America, Europe and Soviet Union 10-year. There are more countries whose compulsory education extends to the first stage (junior high school) of the second level education than those whose compulsory education only includes the first level education. The World Education Report of 1998 indicates that among 171 countries whose data are available, the mean length of compulsory education is 8-year, the mean length of compulsory education in Africa reaches 7.2-year, and the man length of compulsory education developed countries in north America and Europe is 10 to 12 years. The length of compulsory education is compulsorily regulated by the 
legislation or policies of the state and is a mark of the development level of compulsory education of a country. Generally speaking, the length of compulsory education in developed countries is longer than those in developing countries. The five to eight year compulsory education is mainly carried out by developing countries. The length of compulsory education of developed countries is 9 to 12 years. The longer the compulsory education of a country is, the higher the popularization degree and development level of the education is. The input of compulsory education is determined by how much the state financial investment in education accounts for the national citizen incomes or GNP. Comparatively speaking, the GNP of developed countries is higher than that of developing countries. Therefore, the investment in compulsory education of developed countries is certainly higher than that in developing countries.

\section{Retrospect, current station and prospect of China's compulsory education}

Compulsory education is education thought which appeared at the end of Qing Dynasty. It basic opinion is that all citizens should receive compulsory and common preliminary education. Bourgeois reform class, at an earlier time, held that we should imitate European and Japanese capitalism countries to set up schools all over China and to execute compulsory education. Kang Youwei proposed that, "all towns shall set up elementary schools and all citizens at the age of higher than 7 shall receive education on literature, history, mathematics, geography, physics, and music. After 8 years, students could graduate. The parents of those who refuse to enter school shall be punished." Liang Qichao also hold that the elementary education shall be compulsory education. Such opinion was accepted by the advanced knowledge field and education field of that time and therefore was widely spread. Afterwards, "Guimou system" regulates that the length of compulsory education is 5 years. After the Xinhai revolution, "Renziguichou system" regulates that four years of elementary school is compulsory education. In January 1956, the 12-year Education Planning Outline published by the Ministry of Education promises to popularize compulsory education, which says that "the compulsory education will be basically popularized across the entire country within 7 years". In September the same year, in the political report made by Liu Shaoqi in the eighth conference of Communist Party of China, it changes "the compulsory education will be basically popularized' into the compulsory education will be popularized'. However, the duration is changed from 7 years to 12 years. It is first fixed in the form of law in P.R.C. Constitution passed in 1982 in the fifth national conference that China will popularize preliminary compulsory education. In 1986, the P.R.C Compulsory Education Law was promulgated, which is considered as a milestone in the reform and development of China's fundamental education.

It is 20 years from P.R.C Compulsory Education Law was promulgated in 1986 to the amendment made to P.R.C. Compulsory Education Law. During the 20 years, the popularization of compulsory education in China achieves remarkable achievements. China realized historical improvement. In 2005, the population covering rate in areas where the 9 year compulsory education is popularized reaches more than 95\%. During the Eleventh Five Year Plan, China popularized 9 year compulsory education. Since the spring term of 2006, the central government has been emphasizing the support for the system of guaranteeing the execution of countryside compulsory education in the west. The same significance is attached to the poor areas in the east. Countryside students are exempted from the miscellaneous fees at the stage of compulsory education. Students from poor families will enjoy free text books and subsidy form living and accommodation. The guarantee level of the public funds in countryside elementary and junior high schools is increased. The system for guaranteeing the salaries of teachers in elementary and junior high schools shall be consolidated and perfected. This reform fully incorporates countryside compulsory education into the guarantee scale of public finance, relieves the education burden of farmers, and further promotes the popularization of 9 year compulsory education. In 2007, China continues exempting children from low-guarantee families and especially-poor families who formerly enjoy "two-exemption and one-subsidy", orphans and disabled children who are studying public schools from text book fees and further carries out the policy of offering living expense subsidy to boarders from financially difficult families who are receiving compulsory education in the countryside. Countryside students who are receiving compulsory education will be provided with free text books. The basic individual student public fund standard in middle and western providences for elementary and junior high students at the stage of compulsory education shall be increased. The benchmark ration will be fixed so as to warrant that the teaching funds in elementary and junior high schools will be increased annually.

In the two national conferences of 2005 , some representatives suggested that 12 year compulsory education shall be the new aim of education. The author thinks that it is of great meanings to execute 12 year compulsory education. As is well known, the senior high education lays between the compulsory education and the college education, which is not the statutory compulsory education or the higher education that the state supports. Therefore, senior high education becomes a week point in the national education chain. On the other hand, due to the insufficiency in the investment in senior high education, the miscellaneous fees in senior higher educations of many schools are pretty high, which makes poor students stop their studies because they are not able to afford the fees. It is certain that if the 12 year compulsory education is executed, the afore mentioned problems will be resolved. Of course, some one worries that it is hard for undeveloped areas to burden it. Therefore, we shall take steps to execute the 12 year compulsory education. The state shall, at least, encourage areas with developed economy to realize 12 year compulsory education earlier. The extension 
of the length of popularization education is determined by the development of modern production's from low to high level at regular pace. The popularization of fundamental education in other countries is also executed step by step and from low to high level. Without the popularization of the 9 year compulsory education, the 12 year compulsory education could only be the castle in the air. With the development of economy and the improvement of people's living standard, the length of compulsory education will certainly gradually be extended.

Education is the hope of a people, the future of a country and the representation of comprehensive national power. Now, the popularization of 9 year compulsory education has been basically realized. To put forward 12 year compulsory education at proper time shall be the direction that we are striving for. Actually, the time comes. First of all, the economic development has provided solid material base for China to execute 12 year compulsory education. Secondly, the successful execution of family planning policy and the change of people's bearing concept make the growth of population under effective control, which remarkable decreases the economic burden in executing 12 year compulsory education. The meaning to execute 12 year compulsory education for those rich families might not be that important. However, for those poor families, the meaning is great. To execute 12 year compulsory education is also of realistic meaning for promoting the improvement of national education level.

The state does not rule that all areas shall execute 9 year compulsory education because the state, at that time, took into consideration of the specific national power. Therefore, to execute 12 year compulsory education shall also start from the reality, take into accounts the different economic development level and financial status of different areas, and develop gradually. No matter it is 9 year compulsory education or 12 year, it is both determined by the economic development level and financial status of our country. Therefore, it is important to do research on compulsory education standard running costs based on the real and specific condition of China.

\section{References}

Ministry of Finance of P.R.C. Implementing Reform on Guaranteeing System of Countryside Compulsory Education Funds. published on 12 February 2007

Ministry of Finance of P.R.C. Notice on Policies of Adjusting and Perfecting Guaranteeing System of Countryside Compulsory Education Funds. Published on 26 November 2007

Ping Zhong Yi De. (1989). World Education Dictionary. Changsha: Hunan Education Press

UNESCO. (1991). World Education Report

Wang, Chengxu. (1982). Comparison Education. Beijing: People Education Press

Zhang, Nianhong. (1988). Education Encyclopedia. Beijing: China Agricultural Science and Technology Press

\section{Note}

this paper is the first one in the subject Research on the Costs of Running Compulsory Education Standards (subject No. 1071149-3-00) 